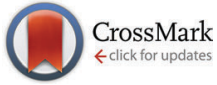

Cite this: Mol. BioSyst., 2016, 12, 1809

Received 6th April 2016,

Accepted 19th April 2016

DOI: $10.1039 / \mathrm{c} 6 \mathrm{mb} 00257 \mathrm{a}$

www.rsc.org/molecularbiosystems

\title{
Photo-crosslinking of clinically relevant kinases using H89-derived photo-affinity probes $\dagger$
}

\author{
Sara C. Stolze, $\ddagger^{a}$ Nora Liu, $\ddagger^{a}$ Ruud H. Wijdeven, Adriaan W. Tuin, ${ }^{a}$ \\ Adrianus M. C. H. van den Nieuwendijk, ${ }^{a}$ Bogdan I. Florea, ${ }^{a}$ Mario van der Stelt, ${ }^{a}$ \\ Gijsbert A. van der Marel, ${ }^{a}$ Jacques J. Neefjes ${ }^{b}$ and Herman S. Overkleeft ${ }^{* a}$
}

\begin{abstract}
The profiling of kinases using established proteomics techniques is hampered by their non-covalent mode-of-action. One way to overcome this caveat is the use of probes featuring photo-labelling groups that can be activated by UV irradiation to generate a reactive species that will establish a covalent bond to the enzyme. In this study we have used the well-known kinase inhibitor H89 as a lead for the development of probes for the affinity-based profiling of clinically relevant kinases. A labelling protocol was established for recombinant kinases and more complex protein mixtures using gel-based techniques. We also show that the probes act in a competitive manner with other kinase inhibitors.
\end{abstract}

\section{Introduction}

The isoquinolinesulfonamide-based kinase inhibitor H89 (1, Scheme 1) was originally identified as a selective and potent inhibitor of protein kinase A (PKA) ${ }^{1}$ and has been used to study the role of PKA in various physiological processes. ${ }^{2} \mathrm{H} 89$ inhibits PKA in an ATP-competitive manner with the bromocinnamoyl sidechain being a crucial factor for the potency and selectivity over other kinases. ${ }^{3}$ Though initially presented as a selective PKA inhibitor, H89 also inhibits a number of other kinases, which is not surprising taking into account that the ATP binding site is conserved in all kinases. ${ }^{2,4} \mathrm{PKB} \alpha$, also referred to as AKT1, is a prominent target of $\mathrm{H} 89$ because of its importance in cancer therapy research. The PI3K/AKT signalling pathway, hyperactivated in many cancer types, ${ }^{5}$ has effects on vital cellular processes such as survival, metabolism, growth and proliferation. ${ }^{6}$ AKT signalling also influences angiogenesis and is involved in metastasis formation via the isoform AKT2. In addition, the PI3K/AKT pathway cross-talks to another critical cell signalling pathway: the Ras/Raf/MEK/ERK signalling cascade. ${ }^{7}$ Aside from its involvement in cancer, AKT1 has also been shown to be a key player in bacterial infections by the regulation of a network of enzymes essential for the survival of pathogens in the phagosomes of host cells. In this context, H89 and its derivative

\footnotetext{
${ }^{a}$ Leiden Institute of Chemistry, Leiden University, Einsteinweg 55, 2300 RA Leiden, The Netherlands. E-mail: h.s.overkleeft@chem.leidenuniv.nl

${ }^{b}$ Division of Cell Biology, The Netherlands Cancer Institute, Plesmanlaan 121, 1066 CX Amsterdam, The Netherlands

$\dagger$ Electronic supplementary information (ESI) available: Kinase screening results (kinomescan), kinetics data for PKA and AKT1 and NMR spectra of all novel compounds. See DOI: $10.1039 / \mathrm{c} 6 \mathrm{mb} 00257 \mathrm{a}$

\$ These authors contributed equally to this work.
}

ETB067 (Scheme 1) were used to distinguish AKT1 from PKA as the crucial enzyme in the control of intracellular bacteria such as Salmonella and M. tuberculosis. ${ }^{8}$ AKT1 inhibitors are the first antibiotic leads described that target host proteins rather than bacterial processes.

In the last few years a number of techniques to profile kinases have emerged, such as the kinobead approach that has recently been used to cluster the activity of well-known inhibitors in a kinome-wide screen. ${ }^{9}$ Another important technique is capture compound mass spectrometry (CCMS), which is based on combining photo-affinity labelling with biotin-based capture techniques in order to pull-down proteins that bind to an inhibitor and have been covalently captured following photo-affinity labelling. This approach has been used to identify targets of dasatinib, imatinib and staurosporine by converting the inhibitors into capture compounds. ${ }^{10}$ The staurosporine capture compound<smiles>[R]C(/C=C\CNCCNS(=O)(=O)c1cccc2cnccc12)=C/c1ccc(Br)cc1</smiles><smiles>[14CH3]C1(c2ccc(/C=C(\CCCN)CNCCNS(=O)(=O)c3cccc4cnccc34)cc2)N=N1</smiles>

Scheme 1 Structures of H89 1 and ETB067 2 (top) and structures of photo-affinity probes $\mathbf{3}$ and $\mathbf{4}$, the subject of the study presented here. 
could also be used in comprehensive kinase profiling due to the broad binding profile of staurosporine. ${ }^{11}$

Finally, covalent irreversible kinase inhibitors have received increasing attention both in drug discovery programs and as starting points for kinase bait design. Most of these mechanismbased inhibitors rely on a cysteine thiol in the proximity of the binding site that is covalently modified upon binding of the inhibitor. ${ }^{12}$ This approach was recently used to target Bruton's tyrosine kinase with Ibrutinib-derived mechanism-based probes. ${ }^{13}$ However, not all kinases possess cysteines near the active site, and this holds true as well for PKA and AKT1. ${ }^{12}$

In this study, we aimed at developing a probe derived from H89 that (a) binds efficiently to our target kinases (PKA, AKT1); (b) contains a photo-activatable group enabling a covalent modification of a captured kinase and (c) carries a conjugation handle to attach a reporter moiety such as a fluorophore or biotin using copper-catalysed click chemistry. The studies on H89 clearly show that the cinnamoyl side chain has an effect on potency and selectivity, ${ }^{3}$ so we decided to retain this moiety in our design and modify the aromatic part of the side chain into an aryl trifluoromethyldiazirine. Based on our studies on ETB067 we reasoned that a modification to the double bond of the cinnamoyl system should not have a major influence on activity and we decided to place a short alkyl chain bearing an azide moiety to enable click labelling.

\section{Results and discussion}

\section{Synthesis of H89-derived photo-affinity probes}

The synthesis of H89-derived photo-affinity probes 3 and 4 (Scheme 2) started from commercially available diethyl cyanomethylphosphonate (5), which was deprotonated with sodium hydride and alkylated with the trityl-protected bromopropanol $6^{14}$ to obtain the mono-alkylated cyanomethyl phosphonate 7 in a yield of $53 \%$. The dialkylation product was also observed and it proved cumbersome to remove this from the desired monoalkyl species during chromatography. Next, the photo-affinity moiety was installed by reacting phosphonate 7 with aldehyde 9 (obtained from known ${ }^{15}$ alcohol 8 by Swern oxidation) in a HornerWadsworth-Emmons reaction yielding the $\alpha$-substituted cinnamonitrile 10 as a $3: 2$ mixture of $E / Z$ isomers in a $79 \%$ yield. The subsequent trans-imination following a 4-step one-pot procedure as developed by Brussee and co-workers ${ }^{16}$ was carried out with the mixture of $E / Z$ isomers. In brief, nitrile $\mathbf{1 0}$ was first reduced with DiBAl-H to obtain the aluminated iminium species, which is then quenched to obtain the primary imine. The latter was then reacted with amine $\mathbf{1 2}$, obtained by activating isoquinoline sulfonic amine $\mathbf{1 1}$ with thionyl chloride and reacting with ethylene diamine. The resulting trans-imination product is more stable than the primary imine formed in the previous step. Finally, the imine was reduced with sodium borohydride to obtain the amine, which was protected with a Boc group after the trityl protection had been removed under acidic conditions. The crude $E / Z$ mixture of isoquinoline amines 13 and 14 could then be separated by HPLC to afford both isomers in pure form.<smiles>O=Cc1ccc(C2(C(F)(F)F)N=N2)cc1</smiles>

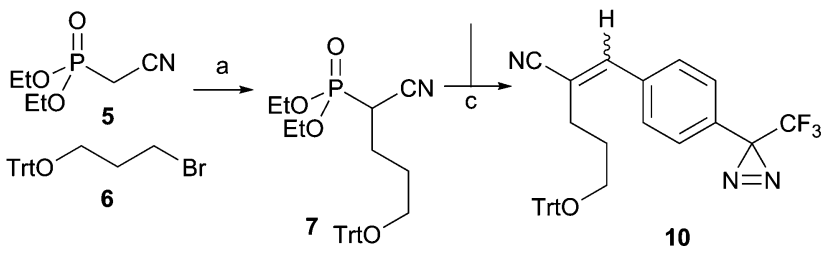

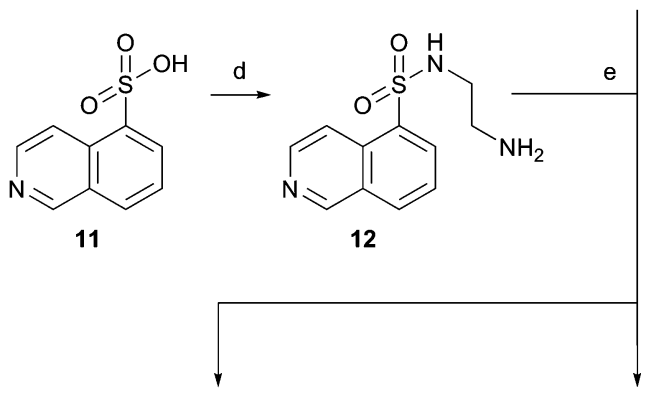<smiles>CC(C)(C)C(=O)NCCNS(=O)(=O)c1cccc2cnccc12</smiles>

Scheme 2 Synthesis of photo-affinity probes. Reagents and conditions: (a) $\mathrm{NaH}, 6,0{ }^{\circ} \mathrm{C}, \mathrm{DMF}, 53 \%$; (b) DMSO, $(\mathrm{COCl})_{2}, \mathrm{TEA},-78{ }^{\circ} \mathrm{C}, 89 \%$; (c) $\mathrm{NaH}$, 9, $0{ }^{\circ} \mathrm{C}, \mathrm{THF}, E / Z=3 / 2,79 \%$; (d) (i) $\mathrm{SOCl}_{2}$, reflux, DMF; (ii) ethylenediamine, DCM, $0{ }^{\circ} \mathrm{C}, 69 \%$; (e) (i) DiBAl-H, $-78{ }^{\circ} \mathrm{C}, \mathrm{Et}_{2} \mathrm{O} / \mathrm{DCM} 1: 1 \mathrm{v} / \mathrm{v}$; (ii) $\mathrm{MeOH}$, $-100{ }^{\circ} \mathrm{C}$; (iii) $12, \mathrm{MeOH}, \mathrm{RT}$; (iv) $\mathrm{NaBH}_{4},-10{ }^{\circ} \mathrm{C}$ to RT; (v) TFA, DCM, $\mathrm{H}_{2} \mathrm{O}$; (vi) $\mathrm{Boc}_{2} \mathrm{O}, \mathrm{TEA}, \mathrm{DCM}, 0{ }^{\circ} \mathrm{C}, 16 \%$ (13); 14\% (14); (f) (i) TEA, DMAP, $\mathrm{TsCl}$, $-20{ }^{\circ} \mathrm{C}, \mathrm{DCM}$; (ii) $\mathrm{NaN}_{3}, \mathrm{DMF}, \mathrm{RT}, 14 \%$ (E); $14 \%$ (Z); (iii) TFA, DCM, RT, $14 \%$ (3); $14 \%(4)$

These were then tosylated and reacted with sodium azide in order to install the bioorthogonal tag. A final deprotection step then yielded photo-affinity probes 3 and 4 in $14 \%$ yield for both probes.

\section{Photo-affinity labelling of PKA and AKT1 using photo-affinity probes 3 and 4}

With probes $\mathbf{3}$ and $\mathbf{4}$ in hand we first set out to establish their inhibitory activity against a panel of kinases. Therefore the probes were subjected to a single point kinase screen (Kinomescan, Leadhunter $)^{17}$ in which the residual kinase activity was determined for one concentration $(10 \mu \mathrm{M})$ of the probes. Probe 3 inhibited both PKA and AKT1 with high activity, whereas probe 4 displayed high activity against PKA and a medium activity against AKT1. Both probes also inhibited the related kinases AKT2 and AKT3, however at a much lower activity, 
Table 1 Enzyme kinetics data for probes 3 and $\mathbf{4}$ determined by FRETassay and Kinomescan ${ }^{17}$

\begin{tabular}{lll}
\hline & PKA & AKT1 \\
\hline Probe 3 & & \\
IC $_{50}$ & $(75.5 \pm 12.54) \mu \mathrm{M}$ & $(3.2 \pm 1.13) \mu \mathrm{M}$ \\
$K_{\mathrm{i}}$ & $(0.61 \pm 0.10) \mu \mathrm{M}$ & $(0.02 \pm 0.00) \mu \mathrm{M}$ \\
Residual activity $^{17}$ & $1.5 \%$ & $2.6 \%$ \\
& & \\
Probe $4^{\text {IC }}$ 50 & & \\
$K_{\mathrm{i}}$ & $(74.7 \pm 23.12) \mu \mathrm{M}$ & $(10.5 \pm 4.58) \mu \mathrm{M}$ \\
Residual activity $^{17}$ & $(0.60 \pm 0.10) \mu \mathrm{M}$ & $(0.04 \pm 0.01) \mu \mathrm{M}$ \\
& $3.4 \%$ & $18 \%$
\end{tabular}

as also observed for the H89-derived ETB067 inhibitor. ${ }^{8}$ The complete results of the kinase screen can be found in the ESI. $\dagger$

To further establish the potency of our probes for the targeted kinases, their $\mathrm{IC}_{50}$ values were determined using a FRET-based assay. The results are presented in Table 1.

To our surprise, the observed $\mathrm{IC}_{50}$ and $K_{\mathrm{i}}$ for probes $\mathbf{3}$ and $\mathbf{4}$ on AKT1 proved to be significantly lower than the ones observed for PKA. The trend observed in the Kinomescan for AKT1 is however preserved with probe 4 being less potent than probe 3 for AKT1. A possible explanation for the discrepancy between the assays might be the use of the natural substrate ATP as a competitor to the probes in the FRET-based assay.

Having confirmed the activity of the two probes, we then set out to design a protocol for the photo-labelling of our target kinases PKA and AKT1. Using recombinant PKA and AKT1 we first elucidated a robust protocol for the labelling of the kinases with the respective probe, followed by photo-crosslinking at $350 \mathrm{~nm}$, performed in the caproBox ${ }^{\mathrm{TM}}$ system $^{18}$ (Caprotec Bioanalytics $\mathrm{GmbH}$, Berlin) and a final click reaction with an alkyne-modified Cy5 reporter for in-gel analysis. Using different concentrations of the probes we determined the amounts of probe equivalents required to label the respective kinases. For both PKA and AKT1 5 equivalents of probe $(390 \mathrm{nM}$, PKA; $295 \mathrm{nM}$ AKT1) with respect to the molar amount of kinase were sufficient to label and detect the kinases by in-gel fluorescence
(Fig. 1, lane 3). Already in these initial experiments it became apparent that probe 3 labels both kinases with a higher affinity than probe 4, especially in the case of AKT1. The overall stronger labelling of PKA compared to AKT1 can be explained with a higher specific activity of the commercially obtained kinase. The differences in the labelling of AKT1 are in accordance with the kinetics data. Taking these first results into account, we focused on the evaluation of probe 3 in the following experiments. Subsequently, we set out to prove that the labelling we observed in the initial experiments is truly based on affinity to our target kinases and requires active kinases. To this end, we set out to perform a number of control experiments. In order to establish if the labelling is affinity-based, we mixed our kinases with increasing amounts $(\mathrm{w} / \mathrm{w})$ of a control protein of similar size and incubated with 5 eq. of 3 (Fig. 2, lanes 5-10). The 1:1 controls were also used for further control experiments: one sample was incubated with DMSO and our click mixture to visualize the background from the association of the proteins with the Cy5 dye (Fig. 2, lane 2). A second sample was not irradiated after incubation with the probe, to establish that the UV activation is necessary for labelling (Fig. 2, lane 3). Finally, a third sample was denatured by the addition of SDS and subsequent boiling and then treated with the probe to prove that an active enzyme is required for the labelling (Fig. 2, lane 4). For both PKA and AKT1 the co-incubation experiment with equivalent amounts of a control protein reveals that the labelling of the targeted kinases with our probes is based on the affinity of the probe towards the target. At higher concentrations of control protein an unspecific reaction of the probe with the control protein and a partial loss of signal for the kinase is observed, especially in the case of AKT1.

It has to be noted, however, that throughout all the experiments the labelling of AKT1 was less intense than the labelling of PKA. Since the $\mathrm{IC}_{50}$ values we determined for both kinases are in the same range for probe 3 , this observation could be explained with different specific activities of the recombinant kinases used in the experiments.

\begin{tabular}{|c|c|c|c|c|c|c|c|c|c|}
\hline PKA (100 ng, 77nM) & + & + & + & + & + & + & + & + & + \\
\hline probe conc. (eq.) & 1 & 5 & 10 & 25 & 33 & 50 & 65 & 85 & 100 \\
\hline probe conc. $(\mu \mathrm{M})$ & 0.077 & 0.39 & 0.77 & 1.93 & 2.54 & 3.85 & 5.00 & 6.55 & 7.70 \\
\hline
\end{tabular}

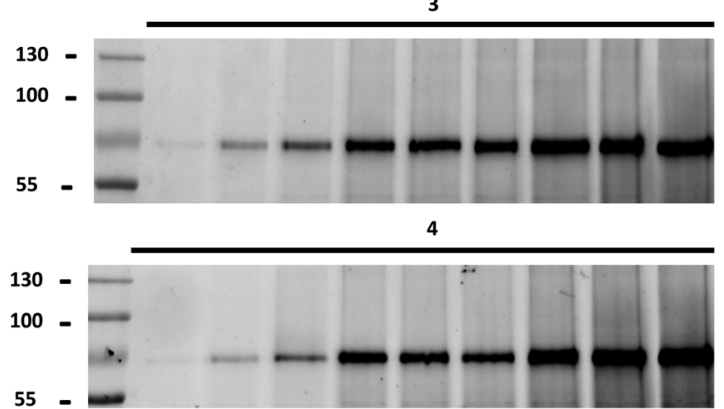

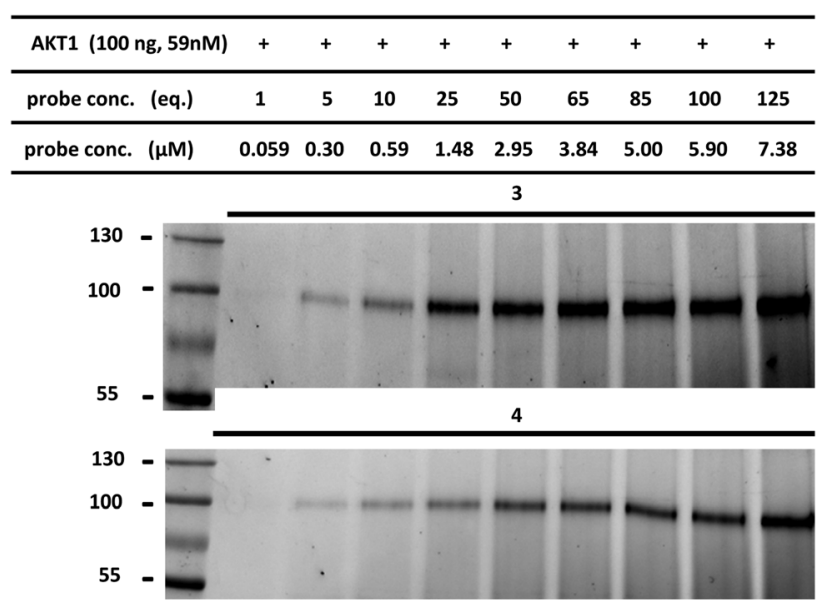

Fig. 1 Initial photo-labelling experiments on recombinant kinases using different probe concentrations. Left panel: Photo-labelling of recombinant PKA using probes $\mathbf{3}$ and $\mathbf{4}$. Right panel: Photo-labelling of recombinant AKT1 using probes $\mathbf{3}$ and $\mathbf{4}$. 


\begin{tabular}{lccccccccc}
\hline PKA $(100 \mathrm{ng})$ & + & + & + & + & + & + & + & + & + \\
\hline Transferrin (x*100 ng) & 1 & 1 & 1 & 0 & 1 & 2 & 5 & 10 & 20 \\
\hline irradiation & - & - & + & + & + & + & + & + & + \\
\hline SDS & - & - & + & - & - & - & - & - & - \\
\hline
\end{tabular}

\begin{tabular}{lcccccccccc}
\hline AKT1 (100 ng) & + & + & + & + & + & + & + & + & + \\
\hline$\beta$-Gal (x*100 ng) & 1 & 1 & 1 & 0 & 1 & 2 & 5 & 10 & 20 \\
\hline irradiation & - & - & + & + & + & + & + & + & + \\
\hline SDS & - & - & + & - & - & - & - & - & - \\
\hline & \multicolumn{7}{c}{$3(295 \mathrm{nM})$} & &
\end{tabular}
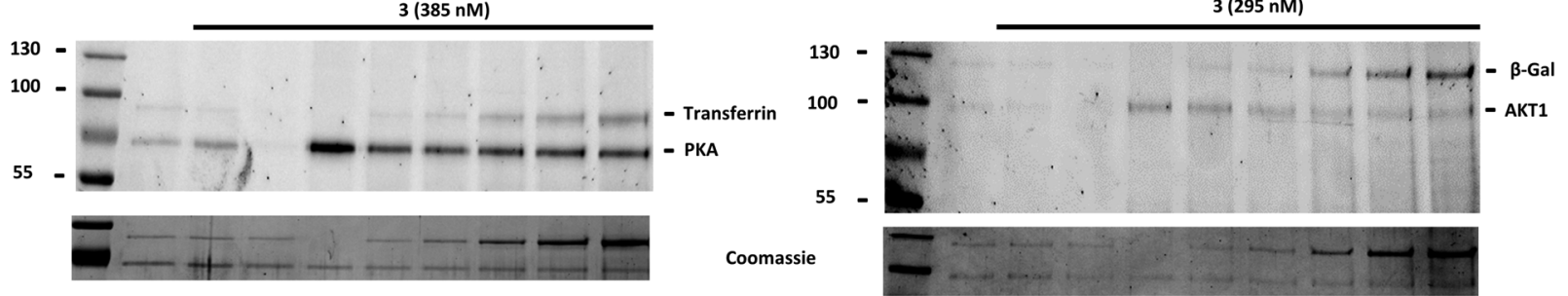

Fig. 2 Control experiments using increasing concentrations of transferrin (PKA, left panel) and $\beta$-galactosidase (AKT1, right panel) as control proteins to determine probe specificity (lanes 5-10). Further controls with 1:1 (w/w) mixtures of kinase and control protein were used to check for background labelling (lane 2), requirement of UV activation (lane 3) and requirement of an active kinase (lane 4).

The additional control experiments proved that an active enzyme is indeed required to achieve labelling proven by the disappearance of the labelled kinase when denaturing the sample before incubation with the probe. Also, the labelling relies on UV irradiation proven by the absence of bands in the non-irradiated samples. In the next set of experiments we focused on visualising the competition between 3 and the well-known broad-spectrum kinase inhibitor staurosporine ${ }^{17}$ and the parent inhibitors to our probes, H89 (1) and ETB067 (2). For PKA we observed a very clear competition when pre-incubating with staurosporine, already at 0.5 equivalents to probe 3 (Fig. 3, upper panel). For AKT1 a competition is observed as well; however, higher concentrations of staurosporine would be required to achieve full competition (Fig. 3, middle panel). Furthermore, the already mentioned lower intensity of labelling for AKT1 not only hampers the visual detection of the competition, but it also hinders an accurate quantification by fluorescence densitometry of the bands due to their low intensity (Fig. 3, lower panel).

In the competition experiments with $\mathrm{H} 89$ and ЕTB067, H89 showed a higher inhibition than ETB067 for both kinases which is in accordance with previously reported $\mathrm{IC}_{50}$ data (Fig. 4$) .{ }^{8}$ For PKA (Fig. 4, left panel) we observed a distinct inhibition profile for increasing concentrations of the competitors both in the visual detection of the bands as well as in the quantification of the detected bands. The apparent poorer inhibition of AKT1 can again be explained with the lower signal intensity.

\section{Attempted pull-down experiments}

With the promising labelling results and competition experiments in hand, we next attempted to perform the photo-labelling procedure with 3 in the more complex environment of a proteomics pull-down experiment. To this end, HeLa cells were infected with $S$. typhimurium which activates AKT1. ${ }^{8}$ The infected cells as well as non-infected controls were lysed and the lysates were subjected to our photo-labelling procedure; downstream processing was executed according to a wellestablished protoco ${ }^{19}$ following analysis by mass spectrometry.

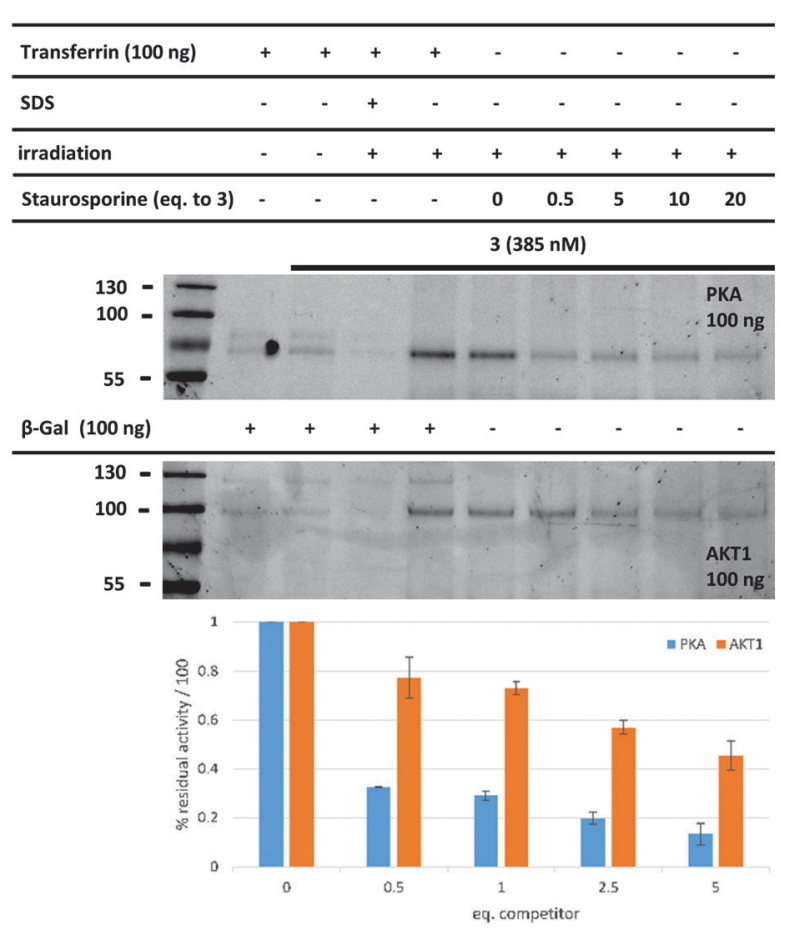

Fig. 3 Competition experiments on PKA (upper panel) and AKT1 (middle panel) using staurosporine as a competitor to probe 3 . The residual activity (lower) was quantified by fluorescence densitometry from $n=3$ experiments.

To our disappointment we were not able to identify AKT1 in the samples generated from the $S$. typhimurium infected cells, or from the control samples. Though we do not have a conclusive explanation for these failed pull-down experiments, there may be several factors involved: too low abundance of AKT1 in the samples, too low affinity of the probe, an inefficient click reaction with biotin-alkyne, a protein sequence that hampers identification or combinations of the factors mentioned. In our case, the fluorescence detection of an enzyme with the probe is more sensitive than the corresponding mass spectrometry. We feel that this might be a matter of quantity and that upscaling our assay would reveal the aimed kinases. 


\begin{tabular}{lcccccccccc}
\hline Transferrin (100 ng) & + & + & + & + & - & - & - & - & - \\
\hline SDS & - & - & + & - & - & - & - & - & - \\
\hline irradiation & - & - & + & + & + & + & + & + & + \\
\hline H89 (eq. to 3) & - & - & - & - & 0 & 0.5 & 5 & 10 & 20 \\
\hline & & & & & $3(385 \mathrm{nM})$ & & &
\end{tabular}
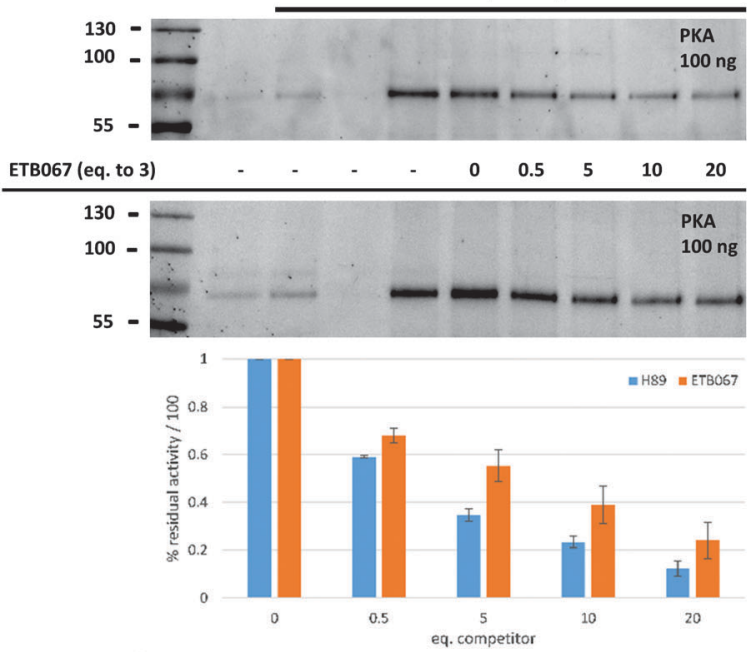

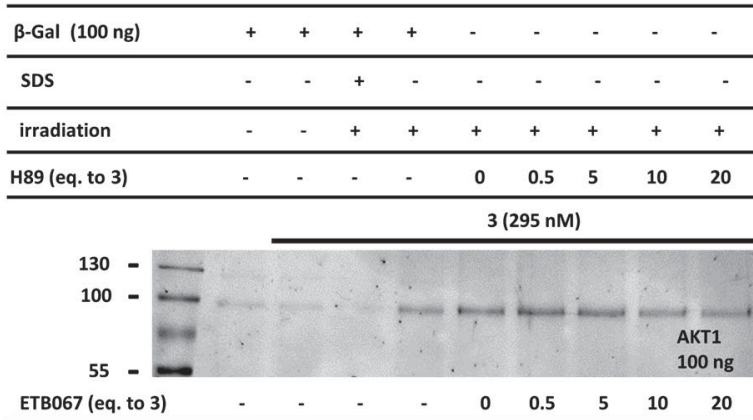

$\mathrm{ETB067}$ (eq. to 3)

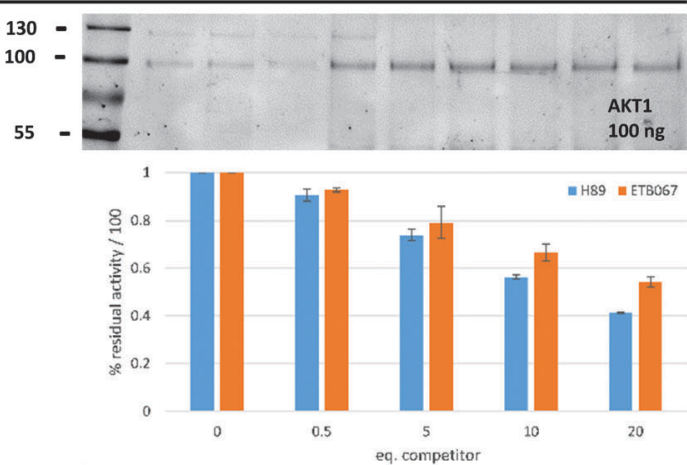

Fig. 4 Competition experiments on PKA (left panel) and AKT1 (right panel) using H89 and ETB067 as competitors to probe 3 . The residual activity (lower) was quantified by fluorescence densitometry from $n=3$ experiments.

\section{Conclusions}

We have designed two photo-affinity probes based on the wellknown kinase inhibitor H89. The probes were tested on a panel of kinases and proved to be inhibitors of both PKA and AKT1. Probe $\mathbf{3}$ has the same double bond configuration as the parent inhibitor H89 and inhibits both PKA and AKT1 with high potency. A change of the double bond configuration to $(Z)$ does not have a significant influence on the inhibition of PKA but for AKT1 a partial loss of potency was observed. This indicates a difference in the periphery of the two kinases and offers a possibility of improving the selectivity towards AKT1. Furthermore, we have proven the efficacy of both probes in the photo-labelling of the clinically relevant kinases PKA and AKT1. Our experiments have however also proven that photo-labelling conditions need to be adjusted for every new target enzyme. We have successfully labelled the recombinant kinases in pure form as well as in mixtures with control proteins; additionally we have performed a variety of control experiments to prove that our probes act in an affinity-based manner on active enzymes and that UV activation is required for labelling. Furthermore, we have performed competition experiments with different kinase inhibitors.

Generating photo-affinity labelled kinase inhibitors will be an attractive method to identify other kinase inhibitors and when used in cell lysates in combination with a conjugation handle - to identify novel inhibitor-novel kinase targets in a relatively unbiased manner. The isolation and identification then have to be improved for the reliable detection of targets. This may be achieved by optimizing the probes with in silico methods for an optimal placement of the photo-affinity group and the isolation handle. Furthermore, alternative bioconjugation handles could improve the isolation of the targeted kinases.

\section{Experimental procedures}

\section{Chemistry}

General materials and methods. Tetrahydrofuran (THF) was distilled over $\mathrm{LiAlH}_{4}$ before use. Acetonitrile (ACN), dichloromethane (DCM), N,N-dimethylformamide (DMF), methanol $(\mathrm{MeOH})$ and trifluoroacetic acid (TFA) were of peptide synthesis grade, obtained from Biosolve, and were used as received. All general chemicals (Fluka, Acros, Merck, Aldrich, Sigma) were used as received. Traces of water were removed from reagents used in reactions that require anhydrous conditions by co-evaporation with toluene. Solvents that were used in reactions were stored over activated 4 A molecular sieves, with the exception of methanol and acetonitrile which were stored over activated $3 \AA$ molecular sieves. Unless noted otherwise all reactions were performed under an argon atmosphere. Column chromatography was performed on Silicycle Silia-P Flash Silica Gel, with a particle size of $40-63 \mu \mathrm{m}$. The eluents toluene and ethyl acetate were distilled prior to use. TLC analysis was conducted on Merck aluminium sheets (Silica gel 60 F254). Compounds were visualized by UV absorption $(254 \mathrm{~nm})$, by spraying with a solution of $\left(\mathrm{NH}_{4}\right)_{6} \mathrm{Mo}_{7} \mathrm{O}_{24} \cdot 4 \mathrm{H}_{2} \mathrm{O}\left(25 \mathrm{~g} \mathrm{~L}^{-1}\right)$ and $\left(\mathrm{NH}_{4}\right)_{4} \mathrm{Ce}\left(\mathrm{SO}_{4}\right)_{4} \cdot 2 \mathrm{H}_{2} \mathrm{O}\left(10 \mathrm{~g} \mathrm{~L}{ }^{-1}\right)$ in $10 \%$ sulphuric acid, a solution of $\mathrm{KMnO}_{4}\left(20 \mathrm{~g} \mathrm{~L}^{-1}\right)$ and $\mathrm{K}_{2} \mathrm{CO}_{3}\left(10 \mathrm{~g} \mathrm{~L}^{-1}\right)$ in water, or ninhydrin $\left(0.75 \mathrm{~g} \mathrm{~L}^{-1}\right)$ and acetic acid $\left(12.5 \mathrm{~mL} \mathrm{~L}^{-1}\right)$ in ethanol, where appropriate, followed by charring at $c a .150{ }^{\circ} \mathrm{C}$. ${ }^{1} \mathrm{H}$ - and ${ }^{13} \mathrm{C}$-NMR spectra were recorded on a Bruker DMX-400 
(400 MHz) or a Bruker DMX-600 (600 MHz) spectrometer. Chemical shifts are given in $\mathrm{ppm}(\delta)$ relative to tetramethylsilane $\left({ }^{1} \mathrm{H}-\mathrm{NMR}\right)$ or $\mathrm{CDCl}_{3}\left({ }^{13} \mathrm{C}-\mathrm{NMR}\right)$ as internal standard. Mass spectra were recorded on a PE/Sciex API 165 instrument equipped with an Electrospray Interface (ESI) (Perkin-Elmer). High-resolution MS (HRMS) spectra were recorded using a Finnigan LTQ-FT (Thermo Electron). IR spectra were recorded on a Shimadzu FTIR-8300 and absorptions are given in $\mathrm{cm}^{-1}$. Optical rotations $[\alpha]_{\mathrm{D}}^{23}$ were recorded on a Propol automatic polarimeter at room temperature. LC-MS analysis was performed on a Jasco HPLC system equipped with a Phenomenex Gemini $3 \mu \mathrm{m} \mathrm{C18} 50 \times$ $4.6 \mathrm{~mm}$ column (detection simultaneously at 214 and $254 \mathrm{~nm}$ ), coupled to a PE Sciex API 165 mass spectrometer with ESI. HPLC gradients were $10 \rightarrow 90 \%, 0 \rightarrow 50 \%$ or $10 \rightarrow 50 \%$ ACN in $0.1 \%$ TFA/ $\mathrm{H}_{2} \mathrm{O}$. Chiral HPLC analysis was performed on a Spectroflow 757 system (ABI Analytical Kratos Division, detection at $254 \mathrm{~nm}$ ) equipped with a Chiralcel OD column $(150 \times 4.6 \mathrm{~mm})$. The compounds were purified on a Gilson HPLC system coupled to a Phenomenex Gemini $5 \mu \mathrm{m} 250 \times 10 \mathrm{~mm}$ column and a GX281 fraction collector. The used gradients were either $0 \rightarrow 30 \%$ or $10 \rightarrow 40 \% \mathrm{ACN}$ in $0.1 \% \mathrm{TFA} /$ water, depending on the lipophilicity of the product. Appropriate fractions were pooled, and concentrated in a Christ rotary vacuum concentrator overnight at room temperature at 0.1 mbar.

Diethyl(1-cyano-4-(trityloxy)butyl)phosphonate (7). To an ice-cold solution of $\mathrm{NaH}$ ( 1 eq., $0.20 \mathrm{~g}, 5.1 \mathrm{mmol}$, $60 \%$ mineral oil) in DMF (15 mL) diethyl cyanomethylphosphonate 5 (0.89 g, $5.0 \mathrm{mmol}$ ) was added slowly and allowed to stir for $30 \mathrm{~min}$ before the addition of ((3-bromopropoxy)methanetrityl)tribenzene 6 ( 1 eq., $1.94 \mathrm{~g}, 5.1 \mathrm{mmol}$ ). The reaction mixture was allowed to warm to RT and then stirred overnight. The mixture was diluted with $\mathrm{H}_{2} \mathrm{O}(75 \mathrm{~mL})$ and $\mathrm{Et}_{2} \mathrm{O}(25 \mathrm{~mL})$; the layers were separated, the aqueous phase was extracted with $\mathrm{Et}_{2} \mathrm{O}(3 \times 25 \mathrm{~mL})$ and the combined organic phases were washed with sat. aq. $\mathrm{NaHCO}_{3}$ and brine, dried over $\mathrm{MgSO}_{4}$, filtered and concentrated in vacuo. The residue was further purified by silica column chromatography $(10 \% \rightarrow 50 \%$ EtOAc/PE) to afford the title compound as a pale yellow oil (yield: $1.27 \mathrm{~g}, 2.7 \mathrm{mmol}, 53 \%) . R_{\mathrm{F}}=0.3(50 \%$ EtOAc/PE). ${ }^{1} \mathrm{H}-\mathrm{NMR}\left(400 \mathrm{MHz}, \mathrm{CDCl}_{3}, \mathrm{Me}_{4} \mathrm{Si}\right) \delta 7.42(6 \mathrm{H}, \mathrm{d}$, $\left.J=7.2 \mathrm{~Hz}, 6 \times \mathrm{CH}_{\mathrm{ar}}\right), 7.29\left(6 \mathrm{H}, \mathrm{t}, J=6.8 \mathrm{~Hz}, 6 \times \mathrm{CH}_{\mathrm{ar}}\right), 7.22(3 \mathrm{H}$, $\left.\mathrm{t}, J=7.2 \mathrm{~Hz}, 3 \times \mathrm{CH}_{\mathrm{ar}}\right), 4.26-4.15\left(4 \mathrm{H}, \mathrm{m}, 2 \times \mathrm{CH}_{2} \mathrm{CH}_{3}\right), 3.14$ $\left(2 \mathrm{H}, \mathrm{t}, J=5.6 \mathrm{~Hz}, \mathrm{CH}_{2} \mathrm{OCPh}_{3}\right), 2.95\left(1 \mathrm{H}, \mathrm{ddd}, J_{1}=4.8 \mathrm{~Hz}, J_{2}=10.4\right.$ $\left.\mathrm{Hz}, J_{3}=23.2 \mathrm{~Hz}, \mathrm{CH}\right), 2.12-2.00\left(1 \mathrm{H}, \mathrm{m}, \mathrm{CH}_{2}-\mathrm{H}^{\mathrm{a}}\right), 1.98-1.90$ $\left(2 \mathrm{H}, \mathrm{m}, \mathrm{CH}_{2}\right), 1.84-1.75\left(1 \mathrm{H}, \mathrm{m}, \mathrm{CH}_{2}-\mathrm{H}^{\mathrm{b}}\right), 1.35\left(6 \mathrm{H}, \mathrm{m}, 2 \times \mathrm{CH}_{3}\right)$. ${ }^{13} \mathrm{C}-\mathrm{NMR}\left(101 \mathrm{MHz}, \mathrm{CDCl}_{3}\right) \delta 143.82,128.40,127.66,126.86$, 116.12, 86.47, 63.84, 63.46, 61.91, 30.18, 28.76, 27.74, 24.22, 16.23. HRMS: calculated for $\mathrm{C}_{28} \mathrm{H}_{32} \mathrm{NO}_{4} \mathrm{P}[\mathrm{M}+\mathrm{H}]^{+}$478.20690; found 478.20372 .

(E/Z)-2-(4-(3-(Trifluoromethyl)-3H-diazirin-3-yl)benzylidene)5-(trityloxy)pentanenitrile (10). To an ice-cold suspension of $\mathrm{NaH}$ (1.1 eq., $0.64 \mathrm{~g}, 15.9 \mathrm{mmol}, 60 \%$ mineral oil) in THF $(75 \mathrm{~mL})$ a solution of phosphonate $7(6.91 \mathrm{~g}, 14.5 \mathrm{mmol})$ in THF $(25 \mathrm{~mL}$ ) was added dropwise and stirred for $30 \mathrm{~min}$. Next, a solution of aldehyde 9 (1.1 eq., $3.45 \mathrm{~g}, 16.6 \mathrm{mmol}$ ) in THF $(10 \mathrm{~mL})$ was added and the reaction mixture was allowed to warm to RT and stirred overnight. The solution was quenched by the addition of freshly prepared sat. aq. $\mathrm{Na}_{2} \mathrm{HSO}_{3}(60 \mathrm{~mL})$ and diluted with $\mathrm{H}_{2} \mathrm{O}(200 \mathrm{~mL})$ and $\mathrm{Et}_{2} \mathrm{O}(100 \mathrm{~mL})$. The layers were separated and the aqueous phase was extracted with $\mathrm{Et}_{2} \mathrm{O}$ $(3 \times 100 \mathrm{~mL})$. The combined organic layers were washed with sat. aq. $\mathrm{NaHCO}_{3}$ and brine, dried over $\mathrm{MgSO}_{4}$, filtered and evaporated. The residue was further purified by silica column chromatography $(10 \% \rightarrow 80 \%$ toluene/pentane) to afford the title compound as a white solid with an $E / Z$ ratio of $3 / 2$ (yield: $6.16 \mathrm{~g}, 11.5 \mathrm{mmol}, 79 \%) .{ }^{1} \mathrm{H}-\mathrm{NMR}\left(400 \mathrm{MHz}, \mathrm{CDCl}_{3}, \mathrm{Me}_{4} \mathrm{Si}\right.$ ) $\delta 7.62\left(2 \mathrm{H}, \mathrm{d}, J=8.4 \mathrm{~Hz}, 2 \times \mathrm{CH}_{\mathrm{ar}}\right), 7.42(6 \mathrm{H}, \mathrm{d}, J=7.2 \mathrm{~Hz}, 6 \times$ $\left.\mathrm{CH}_{\mathrm{ar}}\right), 7.27-7.15\left(11 \mathrm{H}, \mathrm{m}, 11 \times \mathrm{CH}_{\mathrm{ar}}\right), 6.82(1 \mathrm{H}, \mathrm{s}, \mathrm{CH}), 3.14$ $\left(2 \mathrm{H}, \mathrm{t}, J=5.6 \mathrm{~Hz}, \mathrm{CH}_{2}\right), 2.55\left(2 \mathrm{H}, \mathrm{t}, J=7.2 \mathrm{~Hz}, \mathrm{CH}_{2}\right), 1.98-1.91$ $\left(2 \mathrm{H}, \mathrm{m}, \mathrm{CH}_{2}\right) .{ }^{13} \mathrm{C}-\mathrm{NMR}\left(101 \mathrm{MHz}, \mathrm{CDCl}_{3}\right) \delta 144.02,142.03$, $134.84,130.34,128.71,128.51,128.16,126.94,126.57,121.91$ (q, $198.97 \mathrm{~Hz}), 125.24,118.16112 .96,86.46,61.51,33.51$, 28.23. HRMS: calculated for $\mathrm{C}_{33} \mathrm{H}_{26} \mathrm{~F}_{3} \mathrm{~N}_{3} \mathrm{O}[\mathrm{M}+\mathrm{H}]^{+}$538.20280; found 538.20293.

tert-Butyl(E)-(5-hydroxy-2-(4-(3-(trifluoromethyl)-3H-diazirin3-yl)benzylidene)pentyl)(2-(isoquinoline-5-sulfonamido)ethyl)carbamate (13). A solution of nitrile 10 (3.34 g, $6.2 \mathrm{mmol})$ in anhydrous $\mathrm{Et}_{2} \mathrm{O}(20 \mathrm{~mL})$ and $\mathrm{DCM}(20 \mathrm{~mL})$ was cooled to $-78{ }^{\circ} \mathrm{C}$. DiBAl-H (2 eq., $12.4 \mathrm{~mL}, 12.4 \mathrm{mmol}, 1 \mathrm{M}$ solution in hexanes) was added dropwise and the reaction mixture was allowed to warm to $0{ }^{\circ} \mathrm{C}$ and stirred for $2 \mathrm{~h}$, after which TLC analysis showed the complete consumption of the starting material. Next, the mixture was cooled to $-100{ }^{\circ} \mathrm{C}$ followed by the rapid addition of $\mathrm{MeOH}(13 \mathrm{~mL})$. After $5 \mathrm{~min}$ a solution of isoquinoline amine 12 (2.5 eq., $3.90 \mathrm{~g}, 15.5 \mathrm{mmol}$ ) in $\mathrm{MeOH}$ $(10 \mathrm{~mL})$ was added dropwise and the reaction mixture was allowed to stir at RT overnight. Hereafter, the reaction was cooled to $-10{ }^{\circ} \mathrm{C}$ and $\mathrm{NaBH}_{4}$ (2 eq., $0.47 \mathrm{~g}, 12.4 \mathrm{mmol}$ ) was added and the mixture was allowed to stir for $4 \mathrm{~h}$ at RT. The reaction mixture was diluted with $0.5 \mathrm{M}$ aq. $\mathrm{NaOH}(100 \mathrm{~mL})$ and the layers were separated. The aqueous layer was extracted with DCM $(3 \times 50 \mathrm{~mL})$ and the combined organic phases were washed with $\mathrm{H}_{2} \mathrm{O}(3 \times 50 \mathrm{~mL})$ and brine, dried over $\mathrm{MgSO}_{4}$, filtered and evaporated. The crude product was subjected to the next step without further purification.

The crude product was dissolved in DCM $(20 \mathrm{~mL})$ and TFA $(20 \mathrm{~mL})$ was added dropwise. The reaction mixture was stirred for $30 \mathrm{~min}$ at RT before the addition of $\mathrm{H}_{2} \mathrm{O}(40 \mathrm{~mL})$, and the resulting mixture was stirred for $1 \mathrm{~h}$ at RT. Hereafter, the mixture was co-evaporated with toluene, dissolved in DCM $(70 \mathrm{~mL})$ and cooled in an ice bath. To the mixture $\mathrm{Boc}_{2} \mathrm{O}$ (1.1 eq., $1.49 \mathrm{~g}, 6.8 \mathrm{mmol}$ ) and TEA (4 eq., $3.4 \mathrm{~mL}, 24.8 \mathrm{mmol}$ ) were added and the reaction was allowed to warm to RT and stirred overnight. The reaction mixture was concentrated under reduced pressure and re-dissolved in $\mathrm{H}_{2} \mathrm{O}(50 \mathrm{~mL})$ and EtOAc $(50 \mathrm{~mL})$. The organic layer was washed with sat. aq. $\mathrm{NaHCO}_{3}$ and brine, dried over $\mathrm{MgSO}_{4}$, filtered and concentrated in vacuo. The title compound was obtained after purification by RP-HPLC purification (linear gradient $40 \% \rightarrow 60 \%$ ACN in $\mathrm{H}_{2} \mathrm{O}, 0.1 \%$ TFA, $15 \mathrm{~min}$ ) as a yellow oil (yield: $0.61 \mathrm{~g}$, $0.97 \mathrm{mmol}, 15.8 \%)$.

${ }^{1} \mathrm{H}-\mathrm{NMR}\left(400 \mathrm{MHz}, \mathrm{CDCl}_{3}, \mathrm{Me}_{4} \mathrm{Si}\right) \delta 9.32\left(1 \mathrm{H}, \mathrm{s}, \mathrm{CH}_{\mathrm{ar}}\right)$, $8.58\left(1 \mathrm{H}, \mathrm{d}, J=6.0 \mathrm{~Hz}, \mathrm{CH}_{\mathrm{ar}}\right), 8.39\left(1 \mathrm{H}, \mathrm{d}, J=6.4 \mathrm{~Hz}, \mathrm{CH}_{\mathrm{ar}}\right)$, 
$8.27\left(1 \mathrm{H}, \mathrm{d}, J=7.2 \mathrm{~Hz}, \mathrm{CH}_{\mathrm{ar}}\right), 8.18\left(1 \mathrm{H}, \mathrm{d}, J=8.0 \mathrm{~Hz}, \mathrm{CH}_{\mathrm{ar}}\right), 7.65$ $\left(1 \mathrm{H}, \mathrm{t}, J=7.6 \mathrm{~Hz}, \mathrm{CH}_{\mathrm{ar}}\right), 7.11\left(4 \mathrm{H}, \mathrm{s}, 4 \times \mathrm{CH}_{\mathrm{ar}}\right), 3.99\left(2 \mathrm{H}, \mathrm{s}, \mathrm{CH}_{2}\right)$, $3.65\left(2 \mathrm{H}, \mathrm{t}, J=6.0 \mathrm{~Hz}, \mathrm{CH}_{2} \mathrm{OH}\right), 3.10\left(2 \mathrm{H}, \mathrm{s}, \mathrm{CH}_{2}\right), 2.81(2 \mathrm{H}, \mathrm{t}$, $\left.6.0 \mathrm{~Hz}, \mathrm{CH}_{2}\right), 2.09\left(2 \mathrm{H}, \mathrm{t}, J=8.0 \mathrm{~Hz}, \mathrm{CH}_{2}\right), 1.79-1.74(2 \mathrm{H}, \mathrm{m}$, $\left.\mathrm{CH}_{2}\right), 1.39$ (9H, s, $\left.3 \times \mathrm{CH}_{3}\right) \cdot{ }^{13} \mathrm{C}-\mathrm{NMR}\left(101 \mathrm{MHz}, \mathrm{CDCl}_{3}\right)$ $\delta$ 152.94, 144.56, 139.76, 138.19, 134.37, 133.24, 132.80, 131.05, 129.12, 128.87, 127.87, 127.21, 126.10, 125.76, 121.93 $(\mathrm{q}, J=275.73 \mathrm{~Hz}), 117.31,80.78,61.67,45.76,45.31,41.48$, 31.05, 30.06, 28.18 (q, $J=40.4 \mathrm{~Hz}), 28.10$. HRMS: calculated for $\mathrm{C}_{30} \mathrm{H}_{34} \mathrm{~F}_{3} \mathrm{~N}_{5} \mathrm{O}_{5} \mathrm{~S}[\mathrm{M}+\mathrm{H}]^{+}$634.22327; found 634.22333.

tert-Butyl(Z)-(5-hydroxy-2-(4-(3-(trifluoromethyl)-3H-diazirin3-yl)benzylidene)pentyl)(2-(isoquinoline-5-sulfonamido)ethyl)carbamate (14). This compound was prepared in the same reaction as 13. The title compound was obtained after purification by RP-HPLC purification (linear gradient $40 \% \rightarrow 60 \%$ ACN in $\mathrm{H}_{2} \mathrm{O}, 0.1 \%$ TFA, $15 \mathrm{~min}$ ) as a yellow oil (yield: $0.44 \mathrm{~g}, 0.7 \mathrm{mmol}$, 14\%). ${ }^{1} \mathrm{H}-\mathrm{NMR}\left(400 \mathrm{MHz}, \mathrm{CDCl}_{3}, \mathrm{Me}_{4} \mathrm{Si}\right) \delta 9.31\left(1 \mathrm{H}, \mathrm{s}, \mathrm{CH}_{\mathrm{ar}}\right.$ ), $8.59\left(1 \mathrm{H}, \mathrm{d}, J=6.0 \mathrm{~Hz}, \mathrm{CH}_{\mathrm{ar}}\right), 8.45\left(1 \mathrm{H}, \mathrm{d}, J=6.4 \mathrm{~Hz}, \mathrm{CH}_{\mathrm{ar}}\right), 8.37$ $\left(1 \mathrm{H}, \mathrm{d}, J=6.8 \mathrm{~Hz}, \mathrm{CH}_{\mathrm{ar}}\right), 8.14\left(1 \mathrm{H}, \mathrm{d}, J=7.6 \mathrm{~Hz}, \mathrm{CH}_{\mathrm{ar}}\right), 7.60(1 \mathrm{H}, \mathrm{t}$, $\left.J=7.6 \mathrm{~Hz}, \mathrm{CH}_{\mathrm{ar}}\right), 7.19\left(2 \mathrm{H}, \mathrm{d}, J=8.4 \mathrm{~Hz}, 2 \times \mathrm{CH}_{\mathrm{ar}}\right), 7.10(2 \mathrm{H}, \mathrm{d}$, $\left.J=8.0 \mathrm{~Hz}, 2 \times \mathrm{CH}_{\mathrm{ar}}\right), 6.15(1 \mathrm{H}, \mathrm{s}, \mathrm{CH}), 3.85\left(2 \mathrm{H}, \mathrm{s}, \mathrm{CH}_{2}\right), 3.57$ $\left(2 \mathrm{H}, \mathrm{t}, J=6.0 \mathrm{~Hz}, \mathrm{CH}_{2} \mathrm{OH}\right), 3.35\left(2 \mathrm{H}, \mathrm{bs}, \mathrm{CH}_{2}\right), 3.12(2 \mathrm{H}, \mathrm{t}, J=5.6$ $\left.\mathrm{Hz}, \mathrm{CH}_{2}\right), 2.08\left(2 \mathrm{H}, \mathrm{t}, J=7.2 \mathrm{~Hz}, \mathrm{CH}_{2}\right), 1.67\left(2 \mathrm{H}, \mathrm{bs}, \mathrm{CH}_{2}\right)$, $1.40\left(9 \mathrm{H}, \mathrm{s}, 3 \times \mathrm{CH}_{3}\right) .{ }^{13} \mathrm{C}-\mathrm{NMR}\left(101 \mathrm{MHz}, \mathrm{CDCl}_{3}\right) \delta$ 153.01, $144.63,139.57,138.33$, 134.45, 133.30, 132.95, 131.13, 129.16, 128.93, 128.78, 127.16, 126.21, 125.83, 121.98 (q, $J=275.73 \mathrm{~Hz})$, 117.41, 61.93, 53.55, 46.41, 42.09, 30.95, $28.22(\mathrm{q}, J=40.4 \mathrm{~Hz})$, 28.15. HRMS: calculated for $\mathrm{C}_{30} \mathrm{H}_{34} \mathrm{~F}_{3} \mathrm{~N}_{5} \mathrm{O}_{5} \mathrm{~S}[\mathrm{M}+\mathrm{H}]^{+}$634.22327; found 634.22312 .

tert-Butyl(E)-(5-azido-2-(4-(3-(trifluoromethyl)-3H-diazirin-3yl)benzylidene)pentyl)(2-(isoquinoline-5-sulfonamido)ethyl)carbamate. Alcohol $13(0.16 \mathrm{~g}, 0.26 \mathrm{mmol})$ was dissolved in DCM $(5 \mathrm{~mL})$. After the addition of TEA ( 1 eq., $36 \mu \mathrm{L}, 0.26 \mathrm{mmol})$ and DMAP $(0.64 \mathrm{mg}, 5 \mu \mathrm{mol})$ the resulting mixture was cooled to $-20{ }^{\circ} \mathrm{C}$. A solution of TsCl ( 1 eq., $0.05 \mathrm{~g}, 0.26 \mathrm{mmol}$ ) in DCM $(2 \mathrm{~mL})$ was added dropwise and the reaction mixture was stirred at $-20{ }^{\circ} \mathrm{C}$ for $18 \mathrm{~h}$. Subsequently, $0.1 \mathrm{M}$ aq. $\mathrm{HCl}(10 \mathrm{~mL})$ was added and the layers were separated. The organic layer was washed with $0.1 \mathrm{M} \mathrm{HCl}(10 \mathrm{~mL})$ and brine, dried over $\mathrm{MgSO}_{4}$, filtered and concentrated under reduced pressure. The crude product was subjected to the next step without further purification.

The residue was dissolved in DMF $(10 \mathrm{~mL})$. To this was added $\mathrm{NaN}_{3}$ (10 eq., $0.17 \mathrm{~g}, 2.6 \mathrm{mmol}$ ) and the reaction mixture was stirred at room temperature for $5 \mathrm{~h}$ before being concentrated. The resulting residue was purified by RP-HPLC gradient (linear gradient $40 \% \rightarrow 60 \%$ ACN in $\mathrm{H}_{2} \mathrm{O}, 0.1 \% \mathrm{TFA}, 15 \mathrm{~min}$ ) and the title compound was obtained as a light-yellow oil (yield: $0.44 \mathrm{~g}$, $0.7 \mathrm{mmol}, 14 \%) .{ }^{1} \mathrm{H}-\mathrm{NMR}$ (400 MHz, $\left.\mathrm{CDCl}_{3}, \mathrm{Me}_{4} \mathrm{Si}\right) \delta 9.36(1 \mathrm{H}, \mathrm{s}$, $\left.\mathrm{CH}_{\mathrm{ar}}\right), 8.68\left(1 \mathrm{H}, \mathrm{s}, \mathrm{CH}_{\mathrm{ar}}\right), 8.34\left(1 \mathrm{H}, \mathrm{s}, \mathrm{CH}_{\mathrm{ar}}\right), 8.29(1 \mathrm{H}, \mathrm{d}, J=7.2$ $\left.\mathrm{Hz}, \mathrm{CH}_{\mathrm{ar}}\right), 8.20\left(1 \mathrm{H}, \mathrm{d}, J=8.0 \mathrm{~Hz}, \mathrm{CH}_{\mathrm{ar}}\right), 7.67(1 \mathrm{H}, \mathrm{t}, J=8.0 \mathrm{~Hz}$, $\left.\mathrm{CH}_{\mathrm{ar}}\right)$, 7.16-7.09 (4H, m, $\left.4 \times \mathrm{CH}_{\mathrm{ar}}\right), 6.48(1 \mathrm{H}, \mathrm{s}, \mathrm{CH}), 3.97(2 \mathrm{H}, \mathrm{s}$, $\left.\mathrm{CH}_{2}\right), 3.29\left(2 \mathrm{H}, \mathrm{t}, J=6.4 \mathrm{~Hz}, \mathrm{CH}_{2} \mathrm{~N}_{3}\right), 3.06(2 \mathrm{H}, \mathrm{t}, J=5.6 \mathrm{~Hz}$, $\left.\mathrm{NHCH}_{2}\right), 2.78\left(2 \mathrm{H}, \mathrm{bs}, \mathrm{CH}_{2}\right), 2.05\left(2 \mathrm{H}, \mathrm{t}, J=6.8 \mathrm{~Hz}, \mathrm{CH}_{2}\right), 1.78-$ $1.75\left(2 \mathrm{H}, \mathrm{m}, \mathrm{CH}_{2} \mathrm{CH}_{2} \mathrm{~N}_{3}\right), 1.45\left(9 \mathrm{H}, \mathrm{s}, 3 \times \mathrm{CH}_{3}\right) .{ }^{13} \mathrm{C}-\mathrm{NMR}$ $\left(101 \mathrm{MHz}, \mathrm{CDCl}_{3}\right) \delta 162.54,153.14,145.03,137.93,134.30$, $133.37,132.92$, 131.11, 129.20, 128.97, 128.73, 127.63, 126.31,
125.74, 122.00 (q, $J=275.7 \mathrm{~Hz})$, 117.20, 81.17, 50.82, 45.66, 44.94, 41.87, 30.90, 28.23, 27.43. HRMS: calculated for $\mathrm{C}_{30} \mathrm{H}_{33} \mathrm{~F}_{3} \mathrm{~N}_{8} \mathrm{O}_{4} \mathrm{~S}[\mathrm{M}+\mathrm{H}]^{+}$659.22976; found 659.22963.

(E)- $\mathrm{N}$-(2-((5-Azido-2-(4-(3-(trifluoromethyl)-3H-diazirin-3-yl)benzylidene)pentyl)amino)ethyl)isoquinoline-5-sulfonamide (3). TFA $(0.5 \mathrm{~mL})$ was added to a solution of tert-butyl(E)-(5-azido-2-(4-(3(trifluoromethyl)-3H-diazirin-3-yl)benzylidene)pentyl)-(2-(isoquinoline-5-sulfonamido)ethyl)-carbamate (95 $\mu \mathrm{g}, 0.14 \mathrm{mmol}$ ) in DCM $(0.5 \mathrm{~mL})$. After $1 \mathrm{~h}$ TLC analysis indicated the complete conversion of the starting material. Toluene was added and the mixture was co-evaporated under reduced pressure. In order to remove excess TFA the mixture was co-evaporated twice with toluene. The resulting mixture was purified by RP-HPLC (linear gradient $40 \% \rightarrow 60 \%$ ACN in $\mathrm{H}_{2} \mathrm{O}, 0.1 \%$ TFA, $15 \mathrm{~min}$ ) and the title compound was obtained as a yellowish oil (yield: $0.44 \mathrm{~g}$, $0.7 \mathrm{mmol}, 14 \%) .{ }^{1} \mathrm{H}-\mathrm{NMR}\left(400 \mathrm{MHz}, \mathrm{CDCl}_{3}, \mathrm{Me}_{4} \mathrm{Si}\right) \delta 9.29(1 \mathrm{H}$, $\left.\mathrm{s}, \mathrm{CH}_{\mathrm{ar}}\right), 8.57\left(1 \mathrm{H}, \mathrm{d}, J=4.8 \mathrm{~Hz}, \mathrm{CH}_{\mathrm{ar}}\right), 8.39(1 \mathrm{H}, \mathrm{d}, J=5.2 \mathrm{~Hz}$, $\left.\mathrm{CH}_{\mathrm{ar}}\right), 8.35(1 \mathrm{H}, \mathrm{d}, J=7.6 \mathrm{~Hz}, \mathrm{CH}), 8.15\left(1 \mathrm{H}, \mathrm{d}, J=8.0 \mathrm{~Hz}, \mathrm{CH}_{\mathrm{ar}}\right)$, $7.64\left(1 \mathrm{H}, \mathrm{t}, J=7.6 \mathrm{~Hz}, \mathrm{CH}_{\mathrm{ar}}\right), 7.18\left(2 \mathrm{H}, \mathrm{d}, J=8.4 \mathrm{~Hz}, 2 \times \mathrm{CH}_{\mathrm{ar}}\right)$, $7.11\left(2 \mathrm{H}, \mathrm{d}, J=8.4 \mathrm{~Hz}, 2 \times \mathrm{CH}_{\mathrm{ar}}\right), 6.63(1 \mathrm{H}, \mathrm{s}, \mathrm{CH}), 3.74(2 \mathrm{H}, \mathrm{s}$, $\left.\mathrm{CH}_{2}\right), 3.28\left(2 \mathrm{H}, \mathrm{bs}, \mathrm{CH}_{2} \mathrm{~N}_{3}\right), 3.19\left(2 \mathrm{H}, \mathrm{t}, J=6.4 \mathrm{~Hz}, \mathrm{CH}_{2}\right), 2.33$ $\left(2 \mathrm{H}, \mathrm{t}, J=8.4 \mathrm{~Hz}, \mathrm{CH}_{2}\right), 1.67-1.60\left(2 \mathrm{H}, \mathrm{m}, \mathrm{CH}_{2}\right) \cdot{ }^{13} \mathrm{C} \mathrm{NMR}(101$ $\left.\mathrm{MHz}, \mathrm{CDCl}_{3}\right) \delta 153.96,144.69,136.72,133.95,133.71,133.35$, 132.62, 131.14, 128.92, 128.85, 128.52, 126.48, 126.03, 121.97 (q, $J=274.7 \mathrm{~Hz}$ ), 177.40, 52.68, 50.70, 46.88, 39.07, 31.17, 28.27 (q, $J=41.4 \mathrm{~Hz}), 26.98,25.90$. HRMS: calculated for $\mathrm{C}_{25} \mathrm{H}_{25} \mathrm{~F}_{3} \mathrm{~N}_{8} \mathrm{O}_{2} \mathrm{~S}$ $[\mathrm{M}+\mathrm{H}]^{+}$559.17733; found 559.17750.

tert-Butyl(Z)-(5-azido-2-(4-(3-(trifluoromethyl)-3H-diazirin-3yl)benzylidene)pentyl)(2-(isoquinoline-5-sulfonamido)ethyl)carbamate. An identical method was used as for the synthesis of tert-butyl(E)-(5-azido-2-(4-(3-(trifluoromethyl)-3H-diazirin-3-yl)benzylidene)-pentyl)(2-(isoquinoline-5-sulfonamido)ethyl)-carbamate except that compound $14(0.39 \mathrm{~g}, 0.61 \mathrm{mmol})$ was used as a starting material and the amounts of the other reagents were adjusted accordingly. Purification by RP-HPLC (linear gradient $40 \% \rightarrow$ $60 \%$ ACN in $\mathrm{H}_{2} \mathrm{O}, 0.1 \%$ TFA, $15 \mathrm{~min}$ ) yielded the title compound as a light yellow oil (yield: $0.44 \mathrm{~g}, 0.7 \mathrm{mmol}, 14 \%) .{ }^{1} \mathrm{H}-\mathrm{NMR}$ $\left(400 \mathrm{MHz}, \mathrm{CDCl}_{3}, \mathrm{Me}_{4} \mathrm{Si}\right) \delta 9.35\left(1 \mathrm{H}, \mathrm{s}, \mathrm{CH}_{\mathrm{ar}}\right), 8.65(1 \mathrm{H}, \mathrm{d}, J=$ $\left.6.0 \mathrm{~Hz}, \mathrm{CH}_{\mathrm{ar}}\right), 8.43\left(1 \mathrm{H}, \mathrm{d}, J=6.0 \mathrm{~Hz}, \mathrm{CH}_{\mathrm{ar}}\right), 8.39(1 \mathrm{H}, \mathrm{d}, J=$ $\left.7.2 \mathrm{~Hz}, \mathrm{CH}_{\mathrm{ar}}\right), 8.18\left(1 \mathrm{H}, \mathrm{d}, J=8.0 \mathrm{~Hz}, \mathrm{CH}_{\mathrm{ar}}\right), 7.63(1 \mathrm{H}, \mathrm{t}$, $\left.J=7.6 \mathrm{~Hz}, \mathrm{CH}_{\mathrm{ar}}\right), 7.19-7.13\left(4 \mathrm{H}, \mathrm{m}, 4 \times \mathrm{CH}_{\mathrm{ar}}\right), 6.22(1 \mathrm{H}$, $\mathrm{s}, \mathrm{CH}), 3.87\left(2 \mathrm{H}, \mathrm{s}, \mathrm{CH}_{2}\right), 3.35\left(2 \mathrm{H}, \mathrm{bs}, \mathrm{CH}_{2} \mathrm{~N}_{3}\right), 3.20(2 \mathrm{H}, \mathrm{t}$, $\left.J=6.4 \mathrm{~Hz}, \mathrm{CH}_{2}\right), 3.11\left(2 \mathrm{H}, \mathrm{bs}, \mathrm{CH}_{2}\right), 2.21-2.05\left(2 \mathrm{H}, \mathrm{m}, \mathrm{CH}_{2}\right)$, 1.67-1.63 (2H, m, $\left.\mathrm{CH}_{2}\right), 1.44\left(9 \mathrm{H}, \mathrm{s}, 3 \times \mathrm{CH}_{3}\right) .{ }^{13} \mathrm{C}-\mathrm{NMR}(101$ $\left.\mathrm{MHz}, \mathrm{CDCl}_{3}\right) \delta 153.06,144.79,138.71,138.13,134.41,133.06$, $131.23,129.20,128.78,127.89,127.56,126.40,125.83,122.04$ (q, $J=275.7 \mathrm{~Hz}), 117.37,81.02,53.44,51.33,46.09,42.39,28.24$, 27.26, 25.78. HRMS: calculated for $\mathrm{C}_{30} \mathrm{H}_{33} \mathrm{~F}_{3} \mathrm{~N}_{8} \mathrm{O}_{4} \mathrm{~S}[\mathrm{M}+\mathrm{H}]^{+}$ 659.22976; found 659.22984.

(Z)-N-(2-((5-Azido-2-(4-(3-(trifluoromethyl)-3H-diazirin-3-yl)benzylidene)pentyl)amino)ethyl)isoquinoline-5-sulfonamide (4). An identical method was used as for the synthesis of 3 except that tert-butyl(Z)-(5-azido-2-(4-(3-(trifluoromethyl)-3H-diazirin-3-yl)benzylidene)pentyl)(2-(isoquinoline-5-sulfonamido)ethyl)-carbamate $(0.56 \mathrm{~g}, 0.85 \mathrm{mmol})$ was used as a starting material and the amounts of the other materials were adjusted accordingly. Purification by 
RP-HPLC (linear gradient $40 \% \rightarrow 60 \%$ ACN in $\mathrm{H}_{2} \mathrm{O}, 0.1 \%$ TFA, $15 \mathrm{~min}$ ) yielded the title compound as a light yellow oil (yield: $0.44 \mathrm{~g}, 0.7 \mathrm{mmol}, 14 \%$ ). ${ }^{1} \mathrm{H}-\mathrm{NMR}$ (400 MHz, $\left.\mathrm{CDCl}_{3}, \mathrm{Me}_{4} \mathrm{Si}\right) \delta 9.46$ (1H, bs, $\left.\mathrm{CH}_{\mathrm{ar}}\right), 8.59\left(1 \mathrm{H}, \mathrm{bs}, \mathrm{CH}_{\mathrm{ar}}\right), 8.40\left(1 \mathrm{H}, \mathrm{d}, J=7.2 \mathrm{~Hz}, \mathrm{CH}_{\mathrm{ar}}\right)$, $8.31\left(2 \mathrm{H}, \mathrm{d}, J=8.0 \mathrm{~Hz}, 2 \times \mathrm{CH}_{\mathrm{ar}}\right), 7.76\left(1 \mathrm{H}, \mathrm{t}, J=7.6 \mathrm{~Hz}, \mathrm{CH}_{\mathrm{ar}}\right)$, 7.17-7.12 (4H, m, $\left.4 \times \mathrm{CH}_{\mathrm{ar}}\right), 6.74(1 \mathrm{H}, \mathrm{s}, \mathrm{CH}), 3.82\left(2 \mathrm{H}, \mathrm{s}, \mathrm{CH}_{2}\right)$, $3.31\left(2 \mathrm{H}, \mathrm{t}, J=6.4 \mathrm{~Hz}, \mathrm{CH}_{2} \mathrm{~N}_{3}\right), 3.12\left(2 \mathrm{H}, \mathrm{s}, \mathrm{CH}_{2}\right), 2.98(2 \mathrm{H}$, $\left.\mathrm{s}, \mathrm{CH}_{2}\right), 2.37\left(2 \mathrm{H}, \mathrm{t}, J=7.2 \mathrm{~Hz}, \mathrm{CH}_{2}\right), 1.83-1.76(2 \mathrm{H}, \mathrm{m}$, $\left.\mathrm{CH}_{2}\right) .{ }^{13} \mathrm{C}-\mathrm{NMR}\left(101 \mathrm{MHz}, \mathrm{CDCl}_{3}\right) \delta 150.45,139.88,136.78$, 135.16, 134.62, 134.33, 133.80, 132.40, 132.15, 128.93, 128.59, 127.54, 126.77, $121.94(\mathrm{q}, J=275.7 \mathrm{~Hz}), 119.69,50.55,46.71$, 45.73, 38.87, 31.13, 31.07, 28.20 (q, $J=40.4 \mathrm{~Hz}$ ), 26.98. HRMS: calculated for $\mathrm{C}_{25} \mathrm{H}_{25} \mathrm{~F}_{3} \mathrm{~N}_{8} \mathrm{O}_{2} \mathrm{~S}[\mathrm{M}+\mathrm{H}]^{+}$559.17733; found 559.17753.

$\mathrm{N}$-(2-Aminoethyl)isoquinoline-5-sulfonamide (12). Isoquinoline5-sulfonic acid 11 (20.92 g, $100 \mathrm{mmol})$ was treated with thionylchloride (13 eq., $91.5 \mathrm{~mL}, 1300 \mathrm{mmol}$ ) and a catalytic amount of DMF for $2 \mathrm{~h}$ at reflux. The reaction mixture was concentrated and the residue was thoroughly washed with DCM before being re-suspended in $\mathrm{H}_{2} \mathrm{O}(300 \mathrm{~mL})$ at $0{ }^{\circ} \mathrm{C}$. $\mathrm{NaHCO}_{3}(1$ eq., $8.42 \mathrm{~g}$, $100.2 \mathrm{mmol}$ ) was added portion-wise. Next, the mixture was extracted with DCM $(3 \times 500 \mathrm{~mL})$ and dried over $\mathrm{MgSO}_{4}$. The filtrate was added dropwise to a cooled solution of ethylene diamine (5 eq., $33.4 \mathrm{~mL}, 500 \mathrm{~mL}$ ) in DCM $(250 \mathrm{~mL})$ and the reaction mixture was allowed to warm to RT and stirred for $1 \mathrm{~h}$. The mixture was then concentrated before being washed with brine $(50 \mathrm{~mL})$. The aqueous layer was extracted with DCM $(10 \times$ $50 \mathrm{~mL}$ ) and the combined organic layers were washed with brine (50 mL), dried over $\mathrm{MgSO}_{4}$, filtered and concentrated. The title compound was obtained as a thick yellow oil (yield: $17.3 \mathrm{~g}$, $69 \mathrm{mmol}, 69 \%$ ) and was used without further purification. ${ }^{1} \mathrm{H}-\mathrm{NMR}\left(400 \mathrm{MHz}, \mathrm{CDCl}_{3}, \mathrm{Me}_{4} \mathrm{Si}\right) \delta 9.36\left(1 \mathrm{H}, \mathrm{s}, \mathrm{CH}_{\mathrm{ar}}\right), 8.67$ $\left(1 \mathrm{H}, \mathrm{d}, J=8.4 \mathrm{~Hz}, \mathrm{CH}_{\mathrm{ar}}\right), 8.47-8.43\left(2 \mathrm{H}, \mathrm{m}, 2 \times \mathrm{CH}_{\mathrm{ar}}\right), 8.21(1 \mathrm{H}$, $\left.\mathrm{d}, J=11.2 \mathrm{~Hz}, \mathrm{CH}_{\mathrm{ar}}\right), 7.71,\left(1 \mathrm{H}, \mathrm{t}, J=10.0 \mathrm{~Hz}, \mathrm{CH}_{\mathrm{ar}}\right), 3.45(3 \mathrm{H}, \mathrm{bs}$, $\mathrm{NH}_{2}$ and $\left.\mathrm{NH}\right), 3.00\left(2 \mathrm{H}, \mathrm{t}, J=5.2 \mathrm{~Hz}, \mathrm{CH}_{2}\right), 2.76(2 \mathrm{H}, \mathrm{t}, J=6.0 \mathrm{~Hz}$, $\left.\mathrm{CH}_{2}\right) .{ }^{13} \mathrm{C}-\mathrm{NMR}\left(101 \mathrm{MHz}, \mathrm{CDCl}_{3}\right) \delta$ 153.26, 145.06, 133.46, 133.19, 131.23, 129.01, 125.91, 117.22, 45.12, 40.76.

4-(3-(Trifluoromethyl)-3H-diazirin-3-yl)benzaldehyde (9). A solution of DMSO (2.5 eq., $3.22 \mathrm{~mL}, 45.4 \mathrm{mmol}$ ) was cooled to $-78{ }^{\circ} \mathrm{C}$ and oxalyl chloride (1.3 eq., $2.06 \mathrm{~mL}, 24.0 \mathrm{mmol}$ ) was added dropwise to it. The reaction mixture was stirred for $30 \mathrm{~min}$. at $-78{ }^{\circ} \mathrm{C}$. Next, a solution of alcohol 8 (3.93 g, $18.2 \mathrm{mmol})$ in DCM $(10 \mathrm{~mL})$ was added slowly. The reaction mixture was stirred for $1 \mathrm{~h}$ at $-78^{\circ} \mathrm{C}$ before TEA $(5$ eq., $12.6 \mathrm{~mL}$, $90.8 \mathrm{mmol}$ ) was slowly added at $-78{ }^{\circ} \mathrm{C}$. The reaction mixture was allowed to warm to $0{ }^{\circ} \mathrm{C}$ and was subsequently stirred for $3 \mathrm{~h}$. A cold aqueous solution of $20 \% \mathrm{KH}_{2} \mathrm{PO}_{4}(50 \mathrm{~mL})$ and cold $\mathrm{H}_{2} \mathrm{O}(200 \mathrm{~mL})$ was added and the resulting mixture was stirred for $15 \mathrm{~min}$ at RT. The mixture was diluted with $\mathrm{Et}_{2} \mathrm{O}(200 \mathrm{~mL})$ and the layers were separated. The organic layer was washed with a cold aqueous solution of $10 \% \mathrm{KH}_{2} \mathrm{PO}_{4}(3 \times 50 \mathrm{~mL})$ and brine, dried over $\mathrm{MgSO}_{4}$, filtered and evaporated in vacuo. The obtained material was purified by column chromatography $(1 \%$ EtOAc/PE $\rightarrow 5 \%$ EtOAc/PE) and the product was obtained as a pale yellow oil (yield: $3.45 \mathrm{~g}, 16.12 \mathrm{mmol}, 89 \%) .{ }^{1} \mathrm{H}-\mathrm{NMR}$ (400 MHz, $\mathrm{CDCl}_{3}, \mathrm{Me}_{4} \mathrm{Si}$ ) $\delta 10.05$ (1H, s, CHO), 7.91 (2H, d,
$\left.J=8.4 \mathrm{~Hz}, 2 \times \mathrm{CH}_{\mathrm{ar}}\right), 7.34\left(2 \mathrm{H}, \mathrm{d}, J=8.0 \mathrm{~Hz}, 2 \times \mathrm{CH}_{\mathrm{ar}}\right) .{ }^{13} \mathrm{C}-\mathrm{NMR}$ $\left(101 \mathrm{MHz}, \mathrm{CDCl}_{3}\right) \delta 190.85,136.73,134.99,129.65,126.77$, 121.69 (q, $J=275.73 \mathrm{~Hz}), 28.31$ (q, $J=41.41 \mathrm{~Hz}$ ). HRMS: calculated for $\mathrm{C}_{9} \mathrm{H}_{5} \mathrm{~F}_{3} \mathrm{~N}_{2} \mathrm{O}[\mathrm{M}+\mathrm{H}]^{+}$215.03540; found 215.03549.

\section{Biochemistry}

IC $_{50}$ and $\boldsymbol{K}_{\mathbf{i}}$ determination by a FRET assay. Kinase activity was measured using a FRET-based assay with a peptide from ribosomal protein S6 as the substrate. A $10 \mathrm{nM}$ ULight-rpS6 peptide (Perkin-Elmer) was incubated with $100 \mu \mathrm{M}$ ATP and a $2 \mathrm{nM}$ Eu-labeled anti-phospho-rpS6 antibody (Perkin-Elmer, recognizing pSer S6 at position 235 and 236) in HEPES buffer (50 mM HEPES pH 7.5, 1 mM EGTA, $10 \mathrm{mM} \mathrm{MgCl}_{2}, 2 \mathrm{mM}$ DTT and $0.01 \%$ Tween-20) together with $0.5 \mathrm{nM} \mathrm{min}^{-1}$ Akt1 or

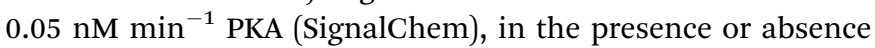
of the probe. During incubation at RT, the intensity of the light emission was measured at intervals of $60 \mathrm{~min}$ on a PE Envision reader using the Lance Ultra kinase assay settings $\left(\lambda_{\text {ex }} 320 \mathrm{~nm}\right.$; $\lambda_{\text {em }} 665 \mathrm{~nm}$ ) and a secondary control emission was measured at $615 \mathrm{~nm}$. In control experiments, no ATP was added to the buffer. Data were analyzed using GraphPad Prism 5 (GraphPad software, La Jolla, USA).

To determine the $K_{\mathbf{M}}$ for the kinases, the same assay was performed using a fixed concentration of the probe $(2 \mu \mathrm{M})$ and $0,0.1,0.2,0.5,1,2,5,10,20,50,100,200,500$, and $1000 \mu \mathrm{M}$ ATP. $K_{M}$ values were calculated using GraphPad Prism 5 (GraphPad software, La Jolla, USA).

$K_{\mathrm{i}}$ values were calculated via eqn (1.1):

$$
K_{\mathrm{i}}=\mathrm{IC}_{50} /\left(1+\left([\mathrm{S}] / K_{\mathrm{M}}\right)\right)
$$

where $K_{\mathrm{i}}$ is the inhibition constant, $\mathrm{IC}_{50}$ is the half maximal inhibitory concentration, $\mathrm{S}$ is the concentration of the substrate and $K_{\mathrm{M}}$ is the Michaelis-Menten constant, which is the substrate concentration at which the reaction rate is half maximum. All experiments were conducted in triplicate and curves were corrected for the background fluorescence of the solvent.

Photo-labelling of recombinant kinases (PKA and AKT1). PKA (PKAc beta) and AKT1 were purchased from Signalchem, aliquoted, stored at $-80{ }^{\circ} \mathrm{C}$ and thawed only once for an experiment.

For pre-denatured samples the solutions were treated with $10 \%$ SDS $(2 \mu \mathrm{L})$ and boiled for 5 min before the addition of the probes. Non-irradiated samples were protected from light by wrapping them in aluminium foil. Competition experiments were performed in triplicate, and the quantification of residual activity was achieved by fluorescence densitometry using the Biorad Image Lab software (version 5.2.1).

In a typical experiment, $100 \mathrm{ng}\left(1 \mu \mathrm{L}\left[100 \mathrm{ng} \mu \mathrm{L}^{-1}\right]\right)$ of recombinant enzyme were added to the assay buffer $(17 \mu \mathrm{L})$ (20 mM HEPES, pH 7.5, $50 \mathrm{mM} \mathrm{KCl,} 10 \mathrm{mM} \mathrm{MgCl}_{2}, 10 \%$ glycerol) (adapted from ref. 11). For competition experiments, the respective inhibitor $(1 \mu \mathrm{L}, 20 \times)$ was added next and the samples were incubated in the dark at RT for $30 \mathrm{~min}$. For all experiments probe 3 , probe $4(2 \mu \mathrm{L}, 10 \times$ or $1 \mu \mathrm{L}, 20 \times$ in competition experiments) or DMSO was added and the samples were incubated for $30 \mathrm{~min}$ at RT in the dark. For irradiation the samples were transferred to a clear, flat-bottom 96-well plate 
and diluted with $30 \mu \mathrm{L}$ of $100 \mathrm{mM}$ HEPES, pH 7.5. The samples were then irradiated for $5 \mathrm{~min}$ at $0{ }^{\circ} \mathrm{C}$ and transferred back into Eppendorf tubes; the concentration was further adjusted by adding $5 \mu \mathrm{L}$ of $100 \mathrm{mM}$ HEPES, $\mathrm{pH}$ 7.5; the untreated samples were diluted in the same way. For the attachment of the Cy5 fluorophore by click reaction samples were treated with the "click mix" ( $6 \mu \mathrm{L}$ per sample), prepared freshly as follows: $3 \mu \mathrm{L}$ of $25 \mathrm{mM} \mathrm{CuSO}_{4}$ (aq.) were mixed with $1.8 \mu \mathrm{L}$ of $0.25 \mathrm{M}$ sodium ascorbate, resulting in a brown solution, which was then vortexed until a colour change to bright yellow was achieved, indicating the reduction of the copper ion. Next, THPTA ${ }^{20}$ $(0.6 \mu \mathrm{L}, 25 \mathrm{mM}$ in DMSO$)$ was added and the mixture vortexed again. Finally, $0.6 \mu \mathrm{L}$ of a $150 \times$ Cy5 alkyne (relative to the amount of probe used in the experiment) was added, and the mixture was vortexed again, added to the sample, mixed and incubated for $1 \mathrm{~h}$ at RT in the dark. The final concentrations of the click reagents were $1.25 \mathrm{mM} \mathrm{CuSO}_{4}, 7.5 \mathrm{mM}$ sodium ascorbate, $250 \mu \mathrm{M}$ THPTA and 1.5 eq. Cy5 alkyne. The reaction was stopped by adding $20 \mu \mathrm{L}$ of SDS loading buffer and boiling for $5 \mathrm{~min}$.

Samples were resolved by $10 \%$ SDS-PAGE; for the in-gel detection of fluorescence bands, wet gel slabs were scanned on the ChemiDoc MP system using Cy5 settings.

\section{Acknowledgements}

The Netherlands Organization for Scientific Research (NWO-CW, Mozaiek Grant, to NL) and the European Research Council (ERC, ERC-2011-AdG-290836, to HSO) are acknowledged for financial support.

\section{References}

1 T. Chijiwa, A. Mishima, M. Hagiwara, M. Sano, K. Hayashi, T. Inoue, K. Naito, T. Toshioka and H. Hidaka, J. Biol. Chem., 1990, 265, 5267-5272.

2 A. Lochner and J. A. Moolman, Cardiovasc. Drug Rev., 2006, 24, 261-274.

3 R. A. Engh, A. Girod, V. Kinzel, R. Huber and D. Bossemeyer, J. Biol. Chem., 1996, 271, 26157.

4 S. P. Davies, H. Reddy, M. Caivano and P. Cohen, Biochem. J., 2000, 351, 95-105.

5 J. A. Engelmann, Nat. Rev. Cancer, 2009, 9, 550-562.

6 B. D. Manning and L. C. Cantley, Cell, 2007, 129, 1261-1274.

7 K. Moelling, K. Schad, M. Bosse, S. Zimmermann and M. Schweneker, J. Biol. Chem., 2002, 277, 31099-31106.
8 C. Kuijl, N. D. L Savage, M. Marsman, A. W. Tuin, L. Janssen, D. A. Egan, M. Ketema, R. van den Nieuwendijk, S. J. F. van den Eeden, A. Geluk, A. Poot, G. van der Marel, R. L. Beijersbergen, H. Overkleeft, T. H. M. Ottenhoff and J. Neefjes, Nature, 2007, 450, 725-730.

9 G. Médard, F. Pachl, B. Ruprecht, S. Klaeger, S. Heinzlmeir, D. Helm, H. Qiao, X. Ku, M. Wilhelm, T. Kuehne, Z. Wu, A. Dittmann, C. Hopf, K. Kramer and B. Kuster, J. Proteome Res., 2015, 14, 1574-1586.

10 J. F. Fischer, C. Dalhoff, A. K. Schrey, O. Y. Graebner, S. Michaelis, K. Andrich, M. Glinski, F. Kroll, M. Sefkow, M. Dreger and H. Koester, J. Proteomics, 2011, 75, 160-168.

11 J. F. Fischer, O. Y. Graebner, C. Dalhoff, S. Michaelis, A. K. Schrey, J. Ungewiss, K. Andrich, D. Jeske, F. Kroll, M. Glinski, M. Sefkow, M. Dreger and H. Koester, J. Proteome Res., 2010, 9, 806-817.

12 T. Barf and A. Kaptein, J. Med. Chem., 2012, 55, 6243-6262.

13 N. Liu, S. Hoogendoorn, B. van der Kar, A. Kaptein, T. Barf, C. Driessen, D. V. Filippov, G. A. van der Marel, M. van der Stelt and H. S. Overkleeft, Org. Biomol. Chem., 2015, 15, 5147-5157.

14 J. Chen, G. Sperl, V. Gullo, L. Sista, D. Hughes, Y. Peng, W. Pierceall, A. Weiskopf, J. Levin, R. Dushin and M. Otteng, US Pat., US20080096903(A1), 2008.

15 M. Wiegand and T. K. Lindhorst, Eur. J. Org. Chem., 2006, 4841-4851.

16 A. M. C. H. van den Nieuwendijk, A. B. T. Ghisaidoobe, H. S. Overkleeft, J. Brussee and A. van der Gen, Tetrahedron, 2004, 60, 10385-10396; P. Zandbergen, A. M. C. H. van den Nieuwendijk, J. Brussee and A. van der Gen, Tetrahedron, 1992, 48, 3977-3982.

17 M. W. Karaman, S. Herrgard, D. K. Treiber, P. Gallant, C. E. Atteridge, B. T. Campbell, K. W. Chan, P. Ciceri, M. J. Davis, P. T. Edeen, R. Faraoni, M. Floyd, J. P. Hunt, D. J. Lockhart, Z. V. Milanov, M. J. Morrison, G. Pallares, H. K. Patel, S. Pritchard, L. M. Wodicka and P. P. Zarrinkar, Nat. Biotechnol., 2008, 26, 127-132.

18 Y. Luo, C. Blex, O. Baessler, M. Glinksi, M. Dreger, M. Sefkow and H. Koester, Mol. Cell. Proteomics, 2009, 8, 2843-2856.

19 N. Li, C.-L. Kuo, G. Paniagua, H. van den Elst, M. Verdoes, L. I. Willems, W. A. van der Linden, M. Ruben, E. van Genderen, J. Gubbens, G. P. van Wezel, H. S. Overkleeft and B. I. Florea, Nat. Protoc., 2013, 8, 1155-1168.

20 T. R. Chan, R. Hilgraf, K. B. Sharpless and V. V. Fokin, Org. Lett., 2004, 6, 2853-2855. 